\title{
EFEKTIFITAS KONSUMSI SELANG DAUN KELOR DAN DAUN MIMBA UNTUK MENGONTROL KADAR GULA DARAH PADA PASIEN DIABETES DI DESA JARIN KECAMATAN PADEMAWU
}

Layla Imroatu Zulaikha, Prodi DIII Kebidanan Universitas Islam Madura

e-mail: aylaathariz@gmail.com

Yulia Paramita, Prodi DIII Kebidanan Universitas Islam Madura

e-mail: yuliayayan@gmail.com

\section{ABSTRACT}

Diabetes mellitus is a disease characterized by high blood sugar levels caused by a disturbance in insulin secretion or insulin related disorders or even both herbal treatments can treat diabetes mellitus and keep the sugar levels normal by restoring the pancreas organ and improving the sensitivity of the cells body. If the pancreas has returned to health then it can automatically perform its function properly ie to produce enough insulin.

This research is a research to examine the effect of treatment on the behavior that arise as a result of treatment. This research was conducted to determine the blood sugar levels after doing the consumption of the hose between the leaves of mimba leaves. The first semester focuses on the effectiveness of blood sugar decrease in diabetic patients with sugar content $<300 \mathrm{gr} / \mathrm{dl}$, with system of daily consumption of hose 3 times with composition of moringa leaf, mimba leaf and moringa leaf. The second semester focuses on the effectiveness of decreasing blood sugar level in diabetic patients with sugar content $<300 \mathrm{gr} / \mathrm{dl}$, with system of daily consumption of 3 times daily with composition of mimba leaves, moringa leaves and leaves.

In addition, the study also obtained information on the effectiveness of Moringa leaf hose and mimba leaves to cope with the increase in blood sugar levels for diabetics.

Keywords: Diabetes mellitus, Moringa Leaves, Mimba Leaves

\section{PENDAHULUAN}

Penyakit Diabetes mellitus ditandai dengan peningkatan kadar gula dalam darah yang disebabakan oleh gangguan pada sekresi insulin atau gangguan kerja insulin atau bahkan keduanya. Diabetes mellitus bukan penyakit baru tetapi sudah ada sejak 1552 SM. Nama diabetes mellitus sendiri diberikan oleh seorang penulis bernama Aretaeu pada tahun 200 SM (Utami,2007). Diabetes artinya mengalir terus dan mellitus artinya manis sehingga lebih dikenal sebagai penyakit kencing manis.

Menurut data dari Federasi Diabetes International IDF Diabetes Atlas, jumlah penderita dibetes ditanah air telah mencapai 8.554.155 orang di tahun 2013. Banyaknya penderita diabetes menempatkan Indonesia menjadi negara dengan populasi penderita diabetes terbanyak ke-7 didunia pada tahun 2013 setelah China, India, Amerika Serikat, Brazil, Rusia dan Meksiko. Bahkan data terbaru oleh PERKENI menunjukkan bahwa angka tersebut semakin naik pada tahun 2014 hingga mencapai 9,1 juta orang. Organisai Kesehatan Dunia WHO Tahun 2035 jumlah penderita Diabetes mellitus diprediksi melonjak hingga ke angka14,1juta orang dengan tingkat prevalensi 6,67 persen untuk populasi orang dewasa (Fitri,2015)

Tujuan pengobatan DM bukan hanya untuk menurunkan kadar gula dalam darah, namun juga bertujuan bahkan mencegah timbulnya komplikasi. Karena penyakit diabetes bersifat menahun maka pengobatan yang dilakukan bertujuan untuk menekan angka angka mortalitas (kematian) dan angka mordibilitas (kesakitan) serta meningkatkan kualitas hidup penderita.

Data Nasional Institutes of Health mengklaim terdapat lebih dari 400 tanaman obat diabetes tradisional di dunia yang mampu mengobati diabetes. Namun hanya sejumlah kecil dari tanaman tradisional ini yang mampu melalui tahapan evaluasi ilmiah untuk menilai efisiensi mereka. Pengobatan kimia memilki dampak buruk bagi kerja ginjal, oleh karena itu banyak penderita diabetes yang beralih menggunakan. Indonesia kaya akan sumber daya alam termasuk berbagai tanaman obat yang dapat digunakan sebagai pengobatan alternatif atau suplemen kesahatan sebagai terapi konvensinal termasuk daun kelor dan daun mimba.

Daun kelor merupakan tanaman asli Indonesia yang sudah banyak dikenal oleh 
masyarakat sampai ke mancanegara. Manfaat daun kelor untuk kesehatan sudah banyak ditemukan oleh para peneliti, bahkan disebut sebagi tanaman ajaib karena dapat digunakan sebagai obat herbal untuk segala penyakit. Daun kelor memiliki kandungan vitamin C lebih banyak dari sayur maupun buah lainnya. Selain daun kelor daun mimba juga dapat mngontrol bahkan menurunkan gula darah. Berdasarkan penelitian, aktivitas hipoglikemik ekstrak daun mimba setingkat dengan glibenklamid. Glibenklamid merupakan bahan aktif yang berfungsi sebagai anti diabetes. Bahan aktif ini banyak ditemukan dalam obatobatan penurun kadar gula darah yang beredar dipasaran. Berdasarkan data itu, ekstrak daun mimba bermanfaat untuk mengontrol gula darah dan mencegah atau menunda terjadinya diabetes melitus.

\section{METODE PENELITIAN}

Kegiatan Penelitian dilakukan di Desa Jarin Kecamatan Pademawu Kabupaten Pamekasan. Secara administrasi Kabupaten Pamekasan terletak pada $6^{\circ} 51^{\prime}-7^{\circ} 31^{\prime}$ lintang selatan dan $113^{\circ} 19^{\prime}-113^{\circ} 58^{\prime}$ bujur timur. Kecamatan Pademawu merupakan kecamatan yang terletak paling selatan dari seluruh kecamatan di Kabupaten Pamekasan. Penelitian di lapangan menggunakan daun kelor dan daun mimba untuk dikonsumsi oleh penderita diabetes. Metode yang digunakan penelitian eksperimen dengan dengan 4kali ulangan. Terdapat 4 perlakuan yang diuji seperti tersusun pada Tabel 1. Perlakuan pengujian pemupukan pada tanaman padi.

\begin{tabular}{|c|l|}
\hline Bulan & \multicolumn{1}{|c|}{ Jenis perlakuan } \\
\hline 1 & $\begin{array}{l}\text { sistem penerapan konsumsi selang } \\
\text { sehari 3kali dengan komposisi daun } \\
\text { kelor,daun mimba dan daun kelor }\end{array}$ \\
\hline 2 & $\begin{array}{l}\text { sistem penerapan konsumsi selang } \\
\text { sehari 3kali dengan komposisi daun } \\
\text { mimba,daun kelor dan daun mimba }\end{array}$ \\
\hline 3 & $\begin{array}{l}\text { sistem penerapan konsumsi selang } \\
\text { sehari 3 kali dengan komposisi daun } \\
\text { kelor }\end{array}$ \\
\hline 4 & $\begin{array}{l}\text { sistem penerapan konsumsi selang } \\
\text { sehari 3kali dengan komposisi daun } \\
\text { kelor }\end{array}$ \\
\hline
\end{tabular}

Kadar Gula darah sebelum diberi perlakuan konsumsi selang antara daun kelor dan daun mimba. Perlakuan dilakukan sebanyak $4 \mathrm{x}$ dengan sistem penerapan konsumsi selang yang berbeda, jenis perlakuan disesuaikan dengan tabel 1. Setelah dilakukan perlakuan yang pertama dilakukan test gula darah untuk menilai perubahan kadar gula darah. Cek gula darah dilakukan stelah satu bulan diberi perlakuan yang berbeda.

Analisis

merupakan

proses memasukkan data agar mudah dimengerti. Analisis induktif digunakan untuk memperoleh data dalam penelitian ini. Analisis data dimulai dengan proses menelaah seluruh data yang telah diperoleh dari hasil pemeriksaan gula darah.Setelah diketahui hasil kadar gula dalam darah kemudian diberikan treatment konsumsi selang antara daun kelor dan daun mimba 3kali dalam sehari dengan komposisi daun kelor,daun mimba dan daun kelor. Setelah semua data terkumpul kemudian peneliti melakukan analisis bivariat yang terdiri dari dua variabel dimana terdapat satu variabel bebas (konsumsi selang antara daun mimba dan daun kelor) dan satu variabel terikat (kadar gula darah) dengan tabulasi silang.

\section{HASIL DAN PEMBAHASAN}

\section{Efektifitas Daun kelor dan Daun Mimba Terhadap kadar Gula dalam Darah}

Kadar Gula darah sebelum dilakukan intervensi selang kelor mimba kelor

Tabel 1: Distribusi frekuensi berdasarkan tipe diabetes responden di Desa Jarin Kecamatan Pademawu Kabupaten Pamekasan

\begin{tabular}{ccc}
\hline $\begin{array}{c}\text { Kadar gula } \\
\text { darah }(\mathrm{gr} / \mathrm{dl})\end{array}$ & Frekuensi & Persentase \% \\
\hline $200-250$ & 11 & 37,00 \\
$251-300$ & 19 & 63,00 \\
\hline Total & 30 & 100 \\
\hline Berdasarkan tabel & 1 & diatas dapat
\end{tabular}
diketahui bahwa dari 30 responden 11 $(37,00 \%)$ responden memiliki kadar gula dalam darah yang berkisar 200-250 gr/dl, sedangkan yang memiliki kadar gula berkisar 251-300 gr/dl sebanyak $21(70,00 \%)$ responden.

Kadar Gula darah setelah dilakukan intervensi konsumsi selang kelor mimba kelor

Tabel 2 :Distribusi frekuensi berdasarkan tipe diabetes responden di Desa Jarin Kecamatan Pademawu Kabupaten Pamekasan

\begin{tabular}{ccc}
\hline $\begin{array}{c}\text { Kadar gula } \\
\text { darah }(\mathrm{gr} / \mathrm{dl})\end{array}$ & Frekuensi & Persentase \% \\
\hline $110-199 \mathrm{gr} / \mathrm{dl}$ & 6 & 20 \\
$200-250 \mathrm{gr} / \mathrm{dl}$ & 10 & 33,33 \\
$251-300 \mathrm{gr} / \mathrm{dl}$ & 14 & 46,67 \\
\hline Total & 30 & 100 \\
\hline Berdasarkan & tabel 2 & diatas dapat
\end{tabular}
diketahui bahwa dari 30 responden $6(20,00 \%)$ responden memiliki kadar gula 110-199 gr/dl atau bisa dikatakan normal, responden 
10(33,33\%) memiliki kadar gula berkisar 200 $250 \mathrm{gr} / \mathrm{dl}$, sedangkan yang memiliki kadar gula berkisar 251-300 gr/dl sebanyak 14 (46,67\%) responden. Perubahan yang sangat signifikan kondisi kadar gula darah setelah mengkonsumsi selang daun kelor daun mimba dan daun kelor. Kondisi ini dibuktikan dengan adanya penderita diabetes yang memiliki kadar gula normal $125 \mathrm{gr} / \mathrm{dl}$ sebnayak 6 orang (20\%). Bukti yang kedua adalah berkurangnya jumlah penderita diabetes pada setiap klasifikasi kelompok penderita diabetes.

3. Kadar Gula darah setelah dilakukan intervensi konsumsi selang mimba kelor mimba

Tabel 3 : Distribusi frekuensi berdasarkan tipe diabetes responden di Desa Jarin Kecamatan Pademawu Kabupaten Pamekasan

\begin{tabular}{ccc}
\hline $\begin{array}{c}\text { Kadar gula } \\
\text { darah }(\mathrm{gr} / \mathrm{dl})\end{array}$ & Frekuensi & Persentase \% \\
\hline $110-199$ & 7 & 23,33 \\
$200-250$ & 13 & 43,33 \\
$251-300$ & 10 & 33,33 \\
\hline Total & 30 & 100 \\
\hline
\end{tabular}

Berdasarkan tabel 3 diatas dapat diketahui bahwa dari 30 responden 7 (23,33\%) responden memiliki kadar gula 110-199 gr/dl atau bisa dikatakan normal, responden $13(43,33 \%)$ memiliki kadar gula berkisar 200 $250 \mathrm{gr} / \mathrm{dl}$, sedangkan yang memiliki kadar gula berkisar 251-300 gr/dl sebanyak 10 $(33,33 \%)$ responden. Perubahan yang sangat signifikan kondisi kadar gula darah setelah mengkonsumsi selang daun mimba, daun kelor dan daun mimba. Dari tabel 7 terlihat perubahan penurunan kadar guladarah, khususnya penderita yang mempunyai kadar gula darah berkisar 251-300 gr/dl.

\section{PENUTUP}

Karakteristik responden

yang mempengaruhi terjadinya diabetes sangat beragam dimulai dari usiayang paling dominan menderita diabetes berkisar antara 41-50 tahun. Selanjutnya jenis kelamin yang juga sangat berpengaruh khususnya perempuan lebih rentan terjadi diabetes yang dipengaruhi oleh gaya hidup terutama pola makan. Pekerjaan juga sangat berpengaruh terhadap terjangkitnya penyakit diabetes, seseorang yang bekerja dengan aktivitas fisik sangt rendah cenderung menderita diabetes, karena gula dalam darah tidak dibakar menjadi energi melainkan berubah menjadi lemak. Tipe diabetes yang menyerang masyarakat desa jarin termasuk klasifikasi diabetes tipe 2, dimana penyebab utamanya adalah gaya hidup dan pola makan.

Hasil eksperimen setelah penderita menerapkan konsumsi selang daun kelor daun mimba dan daun kelor diperoleh data bahwa ada penurunan kadar gula darah pada pasien diabetes.

\section{DAFTAR PUSTAKA}

Anonymous,(2007). Mimba. Bersumber dari www. smallcab. com [diakses tanggal 28 Maret 2016]

Anonymous, (2009). Kandungan Bahan Aktif Mimba. Bersumber dari www. Just aza dira indonesia. blogspot. com [diakses tanggal 28 Maret 2016]

Dokterlndonesia,(2012). Diabetes Pada Anak, Diabetes Mellitus Type1. Bersumber dari dokter indonesia online @gmail.com diakses tanggal 28 Maret 2016]

Fitri,(2015). Prevalensi Penderita Diabetes Di Indonesia. Bersumber dari www.sehatlink.com [diakses tanggal 28 Maret 2016]

Nursalam. (2008). Konsep dan Penerapan Metodologi Penelitian Ilmu Keperawatan. Jakarta: Salemba Medika

Paudi,Febryan.(2014). Berbagai Khasiat Daun Kelor (Edisi Lengkap). Bersumber dari www.berkhasiat.web.id [diakses tanggal 28 Maret 2016]

Putri,OkkiDiana.(2011).Sejuta Khasiat Daun Kelor.Jakarta: Berlian Media

Ramadani,Anisa. (2015). Manfaat Daun Kelor Untuk Diabetes. Bersumber dari www.obat kelenjar.social herbal.xyz [diaksEs tanggal 28 Maret 2016

Rukmana,H. dkk.(2011). Mimba Tanaman Penghasil Pestisida Alami. Yogyakarta: Kansisius

Sitanggang,M. dan Dewani. (2006).Terapi Jus dan 38 Ramuan Tradisional untuk Diabetes. Agromedia Pustaka, Jakarta.

Sugiyono.(2010).MetodePenelitianPendidikan. Bandung:Alfabeta

Trubus,(2011). Kelor Sejuta Khasiat. Bersumber dari www. trubus-online.co.id. 